\title{
Analisis Kesalahan Siswa dalam Menyelesaikan Soal Kemaritiman dengan Prosedur Newman Ditinjau dari Gender
}

\author{
Fadhilah Rahmawati ${ }^{1}$, Nurul Aini Adiningsih ${ }^{2}$, Lia Listiati ${ }^{3}$, Silfiana Sulistyani ${ }^{4}$, Novia Anjani ${ }^{5}$, Bagas Setya \\ Basuki $^{6}$ \\ 123456 Universitas Tidar, Magelang \\ ${ }^{1}$ fadhilahrahmawati@ untidar.ac.id, ${ }^{2}$ nuruladiningsih47@gmail.com, ${ }^{3}$ lialistiati12@ gmail.com, \\ ${ }^{4}$ silfianasulistyani@gmail.com, ${ }^{5}$ novia.anjani31@gmail.com, ${ }^{6}$ Bagas.setya1214@gmail.com
}

Diterima 09 Desember 2020, direvisi 26 Januari 2021, diterbitkan 08 Maret 2021

\begin{abstract}
Abstrak
Penelitian ini bertujuan mendeskripsikan kesalahan siswa dan menjelaskan faktor penyebab kesalahan yang dilakukan siswa dalam menyelesaikan soal kemaritiman berdasarkan prosedur Newman ditinjau dari gender. Pengumpulan data dilakukan dengan tes dan wawancara tidak terstruktur. Jenis penelitian ini adalah penelitian kualitatif deskriptif. Subjek penelitian berjumlah 24 siswa, yaitu 12 siswa laki-laki dan 12 siswa perempuan. Berbagai kesalahan siswa dalam menyelesaikan soal, meliputi: 1) kesalahan dalam membaca; 2) kesalahan dalam memahami; 3) kesalahan dalam transformasi; 4) kesalahan dalam keterampilan proses; dan 5) kesalahan dalam penulisan jawaban. Hasil penelitian menunjukkan perbedaan jenis kesalahan siswa lakilaki dan perempuan dalam menyelesaikan soal kemaritiman. Kesalahan yang paling banyak dilakukan siswa, yaitu kesalahan dalam memahami. Dari hasil penelitian, diperoleh jika siswa laki-laki lebih banyak melakukan kesalahan dalam memahami dibandingkan siswa perempuan. Siswa laki-laki melakukan kesalahan dalam memahami sebesar 63,4\%, sedangkan siswa perempuan melakukan kesalahan dalam memahami sebesar 59,2\%. Hasil penelitian juga menunjukkan bahwa siswa perempuan lebih banyak melakukan kesalahan dalam transformasi, keterampilan proses, dan penulisan jawaban dibandingkan siswa laki-laki.
\end{abstract}

Kata kunci: Kesalahan Newman, Kemaritiman, Gender.

\begin{abstract}
This study aims to describe the students' mistakes and explain the factors causing the errors made by students in solving maritime problems based on the Newman procedure in terms of gender. The data were collected by means of tests and unstructured interviews. This type of research is descriptive qualitative research. The research subjects were 24 students, namely 12 male students and 12 female students. Various students' mistakes in solving questions, including: 1) errors in reading; 2) errors in comprehension; 3) errors in transformation; 4) errors in processing skills; and 5) errors in encoding. The research results showed that there were differences in the types of errors of male and female students in solving maritime questions. The most mistakes made by students, namely errors in comprehension. From the research results, it was found that male students made more errors in compehension than female students. Male students made errors in comprehension by 63,4\%, while female students made errors in comprehension by 59,2\%. The research results also showed that female students made more errors in transformation, process skills, and encoding than male students.
\end{abstract}

Keywords: Newman's Error, Maritime, Gender.

\section{Pendahuluan}

Matematika merupakan ilmu yang mendasari berbagai disiplin ilmu dan mampu meningkatkan 
kemampuan berpikir manusia [1]. Sebagai mata pelajaran penting, matematika berperan cukup besar bagi siswa. Matematika dapat mengembangkan penalaran siswa dalam menyelesaikan permasalahan dalam kehidupan [2]. Oleh karena itu, dapat dikatakan jika matematika mampu mengembangkan siswa untuk berfikir secara kreatif dan logis.

Dalam Ujian Nasional, matematika merupakan mata pelajaran wajib [3]. Salah satu pokok bahasan matematika dalam Ujian Nasional adalah trigonometri [4], namun trigonometri masih menjadi materi yang sukar dipahami siswa. Zain (2017) menyatakan setelah menganalisis hasil kerja siswa, didapatkan sekitar $80 \%$ hasil kerja siswa kurang maksimal. Penyebab hal ini tak lain adalah ketika mengerjakan soal matematika, siswa masih kurang memahami materi sehingga membuat beberapa kesalahan. Permasalahan yang ada, yaitu hal apa saja yang menjadi kesalahan dan mengapa kesalahan tersebut dapat terjadi. Dalam hal ini, perlu adanya analisis agar didapatkan gambaran tentang kelemahan siswa dalam menyelesaikan permasalahan soal [5]. Data tentang kesalahan siswa dalam mengerjakan soal matematika dapat digunakan untuk mengubah kualitas pembelajaran menjadi lebih baik [6].

Terdapat banyak metode analisis kesalahan, salah satu metode yang digunakan adalah prosedur Newman. Menurut Newman [7] terdapat lima kesalahan siswa dalam mengerjakan soal matematika, meliputi: (1) kesalahan membaca, yang disebabkan karena siswa salah dalam membaca soal atau kurang tepat dalam membaca soal dan memaknainya; (2) kesalahan memahami, yang disebabkan karena siswa kurang atau tidak memahami konsep yang ada pada soal sehingga siswa tidak dapat atau kesulitan menyelesaikan permasalahan; (3) kesalahan transformasi, yang disebabkan karena siswa kurang tepat mengubah informasi dalam soal ke bentuk matematika; (4) kesalahan keterampilan proses, yang disebabkan karena siswa kurang tepat dalam melakukan perhitungan; (5) kesalahan penulisan jawaban, yang disebabkan karena siswa kurang teliti atau kurang tepat dalam menuliskan hasil akhir.

Dewasa ini, guru juga perlu mengetahui salah satu faktor yang dapat berpengaruh terhadap siswa dalam menyelesaikan soal permasalahan matematika, yaitu gender. Gender dikenal untuk mengetahui perbedaan non biologis antara lakilaki dan perempuan [8]. Salah satunya dapat digunakan untuk mengidentifikasi perbedaan keterampilan siswa dan siswi dalam mengerjakan soal matematika. Yazidah (2017) menjelaskan jika seluruh siswa dapat mengikuti proses pembelajaran di kelas dalam waktu yang sama dan materi yang sama, tetapi kemampuan memahami pembelajaran yang diberikan oleh guru antara siswa laki-laki dan perempuan berbeda.

Beberapa peneliti mengungkapkan jika terdapat hasil penelitian yang menyatakan adanya pengaruh gender dalam pembelajaran, tetapi juga terdapat penelitian yang menyatakan tidak adanya pengaruh gender dalam pembelajaran [9].

\section{Materi dan Metode}

Subjek pada penelitian ini adalah siswa kelas XI SMA Negeri 2 Grabag sebanyak 24 siswa, terdiri dari 12 siswa laki-laki dan 12 siswa perempuan. Adapun jenis penelitian ini adalah kualitatif deskriptif. Penelitian kualitatif merupakan penelitian yang mana data yang telah diperoleh disajikan dengan suatu pemaparan [10]. Penelitian deskriptif bertujuan untuk memberi gambaran tentang fakta yang ada di lapangan dalam suatu pandangan [11].

Pendekatan yang dilakukan, yaitu studi kasus. Studi kasus merupakan penelitian yang mendetail terhadap suatu hal yang diteliti [12]. Penelitian ini menggunakan instrumen berupa tes tertulis, yaitu 3 soal uraian dan wawancara tidak terstruktur. Pedoman kesalahan Newman akan digunakan untuk menganalisis data yang telah didapatkan dari fakta di lapangan. Dalam penelitian ini, untuk mengetahui persentase jenis kesalahan siswa [13] dihitung sebagai berikut:

\section{Keterangan:}

$$
\mathrm{K}=\frac{\mathrm{B}}{\mathrm{S}} \times 100 \%
$$

$$
\begin{aligned}
& \mathrm{K}=\text { Persentase jenis kesalahan } \\
& \mathrm{B}=\text { Jumlah kesalahan masing-masing jenis } \\
& \quad \text { kesalahan } \\
& \mathrm{S}=\text { Jumlah seluruh kesalahan }
\end{aligned}
$$

Setelah mendapatkan data persentase kesalahan siswa menggunakan rumus diatas, selanjutnya dapat diketahui tingkat kesalahan siswa berdasarkan Tabel 1 berikut [14].

Tabel 1. Pedoman Persentase Tingkat Kesalahan

\begin{tabular}{lll} 
& \multicolumn{2}{c}{ Siswa } \\
\hline No. & Interval & Tingkat Kesalahan \\
\hline 1. & $0 \% \leq P<20 \%$ & Sangat Rendah \\
2. & $20 \% \leq P<40 \%$ & Rendah
\end{tabular}




$\begin{array}{lll}\text { 3. } & 40 \% \leq P<60 \% & \text { Sedang } \\ \text { 4. } & 60 \% \leq P<80 \% & \text { Tinggi } \\ \text { 5. } & 80 \% \leq P<100 \% & \text { Sangat Tinggi }\end{array}$

Soal essay digunakan untuk mengidentifikasi letak kekeliruan siswa [15], sedangkan wawancara tidak terstruktur digunakan untuk mendapatkan data penyebab siswa salah dalam menyelesaikan permasalahan [16]. Analisis data dilakukan melalui pengumpulan data, reduksi data, penyajian data, dan verifikasi data [17]. Reduksi data merupakan proses pemilihan data di lapangan untuk dianalisis berbagai hal yang mempengaruhinya [18].

\section{Hasil dan Pembahasan}

Setelah menganalisis hasil kerja 24 siswa, didapatkan hasil jika masih terdapat banyak kesalahan siswa dalam mengerjakan soal kemaritiman. Dalam penelitian ini siswa mengerjakan 3 soal kemaritiman matematika. Tabel 2 dan 3 berikut adalah data hasil tes siswa berdasarkan Newman's Error Analysis (NEA) ditinjau dari gender.

Tabel 2. Indikator Kesalahan Siswa Laki-laki Berdasarkan Newman's Error Analysis (NEA)

\begin{tabular}{ccccc}
\hline No. & Tahapan & $\begin{array}{c}\text { Jum- } \\
\text { lah }\end{array}$ & $\begin{array}{c}\text { Per- } \\
\text { sen } \\
(\%)\end{array}$ & $\begin{array}{c}\text { Tingkat } \\
\text { Kesalah } \\
\text {-an }\end{array}$ \\
\hline 1. & Reading & 0 & 0 & $\begin{array}{c}\text { Sangat } \\
\text { Rendah }\end{array}$ \\
\hline 2. & $\begin{array}{c}\text { Comprehe } \\
\text { nsion }\end{array}$ & 121 & 63,4 & Tinggi \\
\hline 3. & $\begin{array}{c}\text { Transform } \\
\text { ation }\end{array}$ & 16 & 8,4 & $\begin{array}{c}\text { Sangat } \\
\text { rendah }\end{array}$ \\
\hline 4. & $\begin{array}{c}\text { Process } \\
\text { Skill }\end{array}$ & 27 & 14,1 & $\begin{array}{c}\text { Sangat } \\
\text { rendah }\end{array}$ \\
\hline 5. & Encoding & 27 & 14,1 & $\begin{array}{c}\text { Sangat } \\
\text { rendah }\end{array}$ \\
\hline Jumlah & 191 & 100 & \\
\hline
\end{tabular}

Tabel 3 berikut menginformasikan indikator kesalahan siswa perempuan.

Tabel 3. Indikator Kesalahan Siswa Perempuan Berdasarkan Newman's Error Analysis (NEA)

\begin{tabular}{|c|c|c|c|c|}
\hline No. & Tahapan & $\begin{array}{c}\text { Jum- } \\
\text { lah }\end{array}$ & $\begin{array}{l}\text { Per- } \\
\text { sen } \\
(\%)\end{array}$ & $\begin{array}{l}\text { Tingkat } \\
\text { Kesalah } \\
\text {-an }\end{array}$ \\
\hline
\end{tabular}

\begin{tabular}{ccccc} 
1. & Reading & 0 & 0 & $\begin{array}{c}\text { Sangat } \\
\text { Rendah }\end{array}$ \\
\hline 2. & $\begin{array}{c}\text { Comprehe } \\
\text { nsion }\end{array}$ & 122 & 59,2 & Sedang \\
\hline 3. & $\begin{array}{c}\text { Transform } \\
\text { ation }\end{array}$ & 22 & 10,7 & $\begin{array}{c}\text { Sangat } \\
\text { rendah }\end{array}$ \\
\hline 4. & $\begin{array}{c}\text { Process } \\
\text { Skill }\end{array}$ & 32 & 15,5 & $\begin{array}{c}\text { Sangat } \\
\text { rendah }\end{array}$ \\
\hline 5. & Encoding & 30 & 14,6 & $\begin{array}{c}\text { Sangat } \\
\text { rendah }\end{array}$ \\
\hline Jumlah & 206 & 100 & \\
\hline
\end{tabular}

Dari kedua tabel tersebut, diperoleh bahwa persentase kesalahan terbesar kedua gender ada pada tahap memahami. Hal ini disebabkan karena siswa kurang memahami konsep, siswa tidak mencantumkan hal yang diketahui serta hal yang ditanyakan soal sehingga siswa salah dalam memahami soal. Kesalahan siswa dalam menangkap informasi yang ada pada soal mengakibatkan siswa salah atau tidak dapat menyelesaikan permasalahan. Dari tabel juga diperoleh bahwa persentase kesalahan siswa perempuan lebih besar dibandingkan persentase kesalahan siswa laki-laki pada tahap transformasi, keterampilan proses, dan penulisan jawaban.

Data yang diperoleh dari penelitian ini sesuai dengan penelitian dari Mulyani dan Muhtadi (2019) yang menyatakan persentase kesalahan siswa laki-laki pada tahap keterampilan proses (process skill) sebesar $12,50 \%$, sedangkan persentase kesalahan siswa perempuan sebesar $16,95 \%$. Dan persentase kesalahan siswa lakilaki pada tahap penulisan jawaban (encoding) sebesar 29,69\%, sedangkan persentase kesalahan siswa perempuan sebesar $30,51 \%$. Hasil penelitian ini menunjukkan perlunya penanaman konsep agar siswa dapat memahami lebih mendalam terhadap materi [19].

Pemaparan berikut merupakan hasil pekerjaan siswa yang telah dianalisis berdasarkan Newman's Error Analysis (NEA) dan wawancara tidak terstruktur.

1. Siswa Laki-laki dengan Hasil Belajar Tinggi 


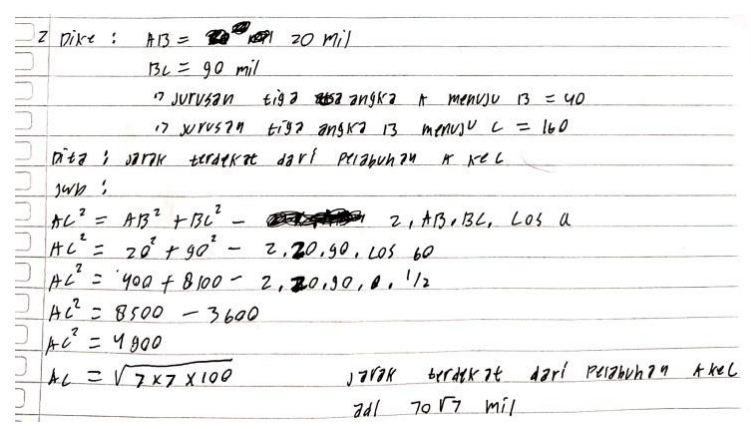

Gambar 1. Hasil Pekerjaan Siswa Laki-laki dengan Hasil Belajar Tinggi

Dari gambar diatas, siswa telah memahami soal, dibuktikan dengan siswa menuliskan hal yang diketahui dan hal yang ditanyakan dalam soal. Dari hasil wawancara, siswa dapat membaca soal dengan benar dan siswa mampu menjelaskan secara tersirat maksud soal. Namun, siswa tidak menyertakan gambar dalam lembar pekerjaannya sehingga terlihat mencantumkan hal yang diketahui dengan simbol yang tidak jelas. Dalam wawancara, siswa mengatakan jika gambar yang dibuatnya lupa dicantumkan di lembar pekerjaan karena tergesa-gesa dalam mengerjakan.

Selain itu, siswa menuliskan jawaban yang tidak tepat meskipun sudah menggunakan rumus dan menyertakan satuan yang sesuai. Ini dikarenakan siswa melakukan kesalahan dalam komputasi, yaitu tidak mengalikannya dengan setengah sehingga hasil akhirnya salah. Dari wawancara, siswa mengatakan jika ia kurang teliti dalam mengerjakan soal karena ingin cepat menyelesaikan pekerjaannya.

2. Siswa Laki-laki dengan Hasil Belajar Sedang

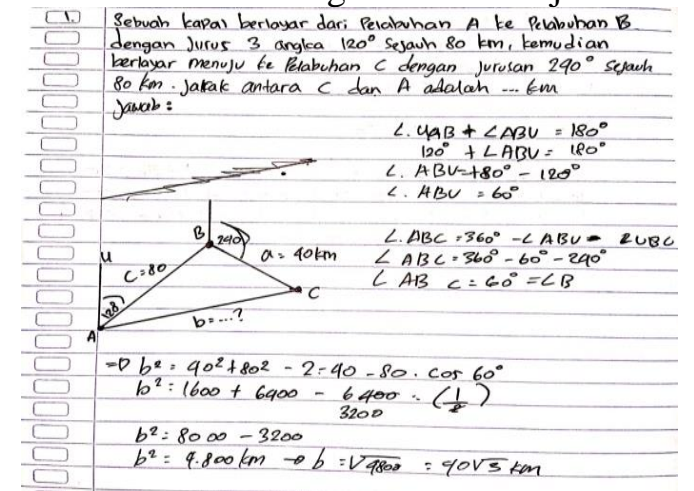

Gambar 2. Hasil Pekerjaan Siswa Laki-laki dengan Hasil Belajar Sedang

Dari gambar diatas dapat dilihat jika siswa sudah cukup memahami soal karena siswa sudah menuliskan sudut yang diketahui. Dari wawancara, siswa dapat membaca soal dengan benar dan siswa mampu menjelaskan maksud dari soal. Namun, siswa belum menuliskan keseluruhan informasi dalam soal. Hal ini mengakibatkan proses komputasi menjadi salah, angka pada komputasi berbeda dengan yang tertera pada soal sehingga jawaban yang dituliskan tidak tepat.

Dalam wawancara siswa mengatakan jika siswa kurang cermat saat mengamati soal yang menyebabkan penulisan angka kurang tepat.

3. Siswa Laki-laki dengan Hasil Belajar Rendah

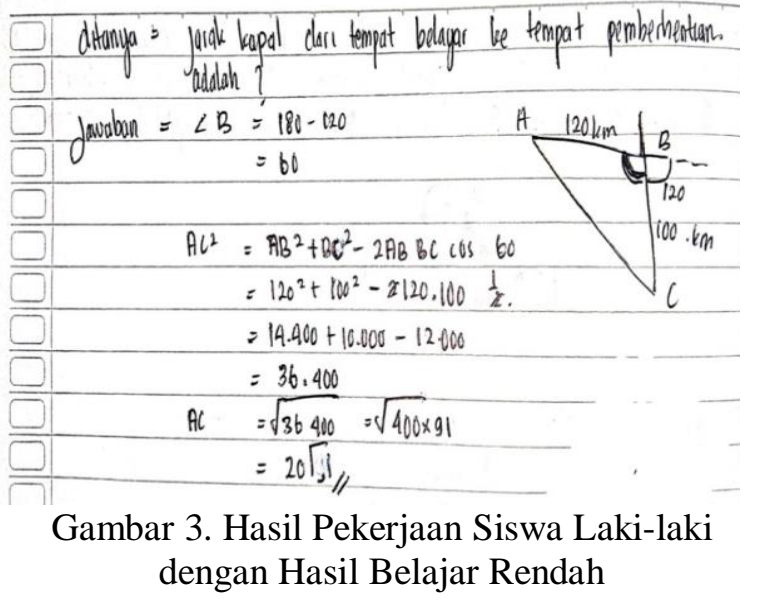

Dari gambar diatas, dapat dilihat jika siswa kurang memahami soal, ini dibuktikan dengan siswa tidak menuliskan hal yang diketahui dan hanya mencantumkan pertanyaan soal. Hal ini menyebabkan siswa menjadi kurang tepat dalam membuat sketsa gambar dari ilustrasi soal.

Dari wawancara, siswa dapat membaca soal dengan benar. Namun, siswa mengatakan alasannya tidak mencantumkan hal yang diketahui karena pada soal sudah tercantum hal yang diketahui, sementara kurang tepatnya sketsa gambar karena ia bingung dalam mencari sudut B. Siswa juga melakukan kesalahan dalam transformasi dibuktikan dalam lembar jawab dan siswa tidak dapat menjelaskannya.

Memahami soal dengan salah membuat siswa melakukan kesalahan di tahap-tahap selanjutnya. Selain itu, siswa juga tidak mencantumkan satuan yang sesuai dengan soal.

\section{Siswa Perempuan Hasil Belajar Tinggi}




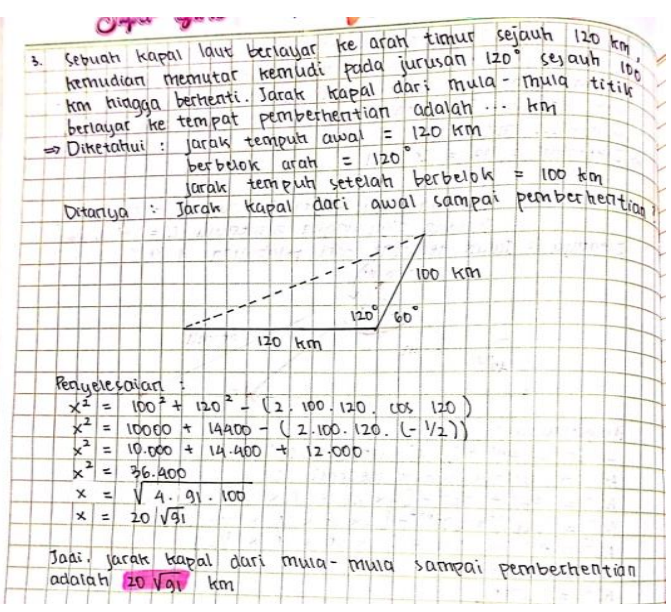

Gambar 4. Hasil Pekerjaan Perempuan dengan Hasil Belajar Tinggi

Dari gambar diatas, siswi sudah memahami soal, terlihat dimana siswi mencantumkan hal yang diketahui dan hal yang ditanyakan. Dari hasil wawancara, siswi dapat membaca soal dengan benar dan siswi mampu menjelaskan secara tersirat maksud soal. Siswi juga sudah menyertakan gambar dalam lembar pekerjaannya. Namun, gambar sketsa ilustrasi tersebut kurang tepat karena ukuran sudut seharusnya diukur ketika kapal dalam posisi tegak. Berdasarkan wawancara siswi mengatakan jika siswi memang menghitungnya dari sudut 0 derajat karena tidak mengetahui jika benda dihitung dalam posisi tegak lurus sehingga siswi melakukan kesalahan dalam gambar. Dalam hal ini dapat diartikan jika siswi salah dalam menafsirkan soal.

Kesalahan dalam membuat sketsa soal membuat jawaban selanjutnya menjadi salah. Meskipun, satuan yang dicantumkan telah sesuai dan proses komputasi telah benar, tetapi angka yang seharusnya dihitung salah.

5. Siswa Perempuan dengan Hasil Belajar Sedang

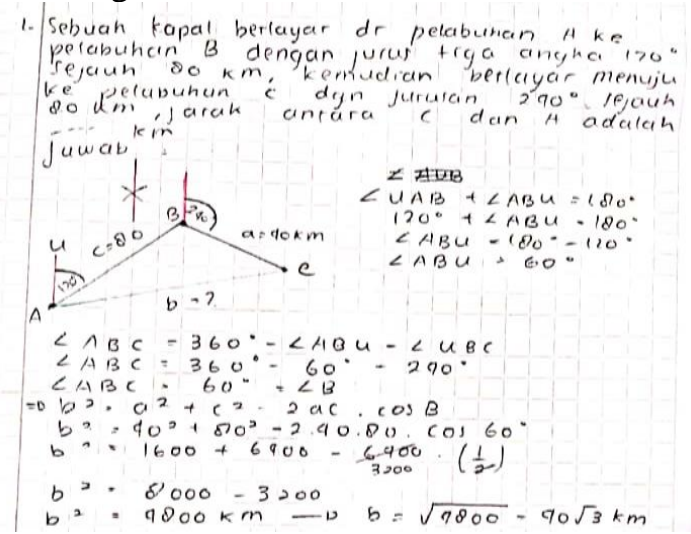

Gambar 5. Hasil Pekerjaan Perempuan dengan Hasil Belajar Sedang
Dari gambar diatas dapat dilihat jika siswi sudah cukup memahami soal karena siswi sudah mencantumkan besaran sudut-sudut yang diketahui. Berdasarkan hasil wawancara, siswi dapat membaca soal dengan benar dan siswi mampu menjelaskan secara tersirat maksud soal. Namun, siswi belum menuliskan keseluruhan informasi yang dalam soal dan hal yang ditanyakan juga tidak dituliskan yang mengakibatkan siswi salah pada komputasi. Walaupun, siswi dapat menjelaskan proses komputasi dalam lembar jawab, tetapi siswi menuliskan angka yang berbeda dalam komputasi sehingga siswi menuliskan jawaban yang tidak tepat. Dalam wawancara, siswi mengatakan jika ia kurang teliti dalam mencermati soal sehingga angka yang dicantumkan tidak tepat.

6. Siswa Perempuan dengan Hasil Belajar Rendah

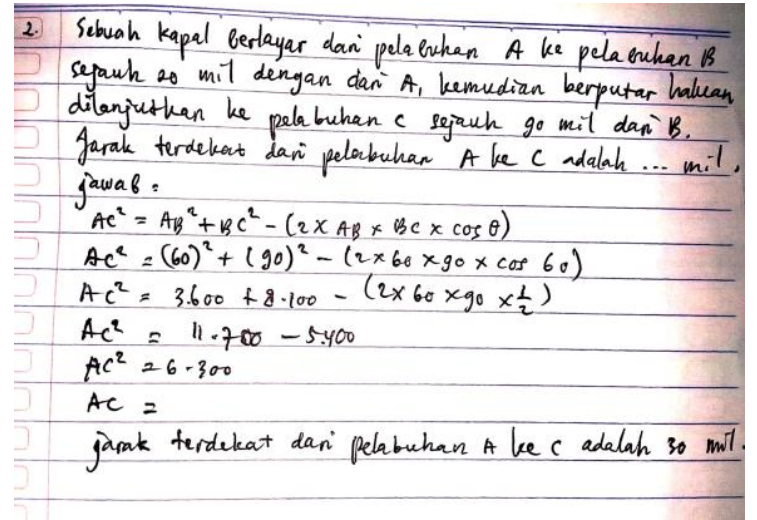

Gambar 6. Hasil Pekerjaan Perempuan dengan Hasil Belajar Rendah

Dari gambar diatas, terlihat jika siswi kurang memahami soal, siswi tidak mencantumkan hal yang diketahui dan tidak mencantumkan juga hal yang ditanyakan dalam soal. Siswi juga tidak menggambar sketsa soal sehingga hal ini menyebabkan siswi salah pada penyelesaian tahap selanjutnya. Meskipun, ia sudah menggunakan rumus yang tepat, tetapi ia tetap menuliskan jawaban yang tidak benar.

Setelah dilakukan wawancara, siswi memang biasa menjawab soal tanpa menggambar dan tanpa menuliskan hal yang diketahui serta ditanya dalam soal. Namun, siswi dapat membaca soal dengan benar. Untuk kesalahan penulisan angka disebabkan karena siswi kurang teliti dan tergesa-gesa sehingga ia salah mencantumkan angka dalam lembar jawabnya.

Terdapat penelitian yang sejalan dengan penelitian ini yang mana menyatakan bahwa 
terdapat beberapa jenis kesalahan siswa dalam menyelesaikan soal, yaitu 1) kesalahan fakta merupakan tidak lengkap mencantumkan hal yang diketahui soal dan salah menuliskan simbol-simbol matematika; 2) kesalahan konsep merupakan kekeliruan memaknai konsep soal; 3) kesalahan prinsip merupakan kekeliruan dalam penulisan hasil akhir dan kesimpulan; 4) kesalahan operasi merupakan kekeliruan siswa dalam menghitung [20].

\section{Kesimpulan}

1. Terdapat beberapa kesalahan siswa dalam menyelesaikan soal kemaritiman berdasarkan teori Newman, yaitu kesalahan pada tahap memahami, kesalahan pada tahap transformasi, kesalahan pada tahap keterampilan proses, dan kesalahan pada tahap penulisan jawaban.

2. Adanya pengaruh gender dalam menyelesaikan soal kemaritiman, yaitu persentase kesalahan siswa perempuan pada tahap pemahaman lebih sedikit dibandingkan siswa laki-laki, siswa perempuan melakukan kesalahan dalam memahami sebesar 59,2\%, sedangkan siswa laki-laki melakukan kesalahan dalam memahami sebesar $63,4 \%$. Hal ini dikarenakan beberapa siswa perempuan menuliskan hal yang diketahui dan hal yang ditanyakan soal sehingga siswa perempuan menangkap informasi yang ada yang mengakibatkan siswa perempuan lebih memahami konsep. Hasil penelitian juga menunjukkan bahwa persentase kesalahan siswa perempuan lebih banyak pada tahap transformasi, keterampilan proses, dan penulisan jawaban dibandingkan persentase kesalahan siswa laki-laki.

\section{Saran}

Diharapkan penelitian ini dapat dijadikan rujukan untuk menentukan pendekatan yang sesuai dalam pembelajaran sehingga dapat mengurangi tingkat kesalahan siswa dalam menyelesaikan soal kemaritiman dan diharapkan penelitian ini dapat dikembangkan dalam berbagai aspek lainnya.

\section{Ucapan terima kasih}

Penulis mengucapkan terima kasih kepada Ibu Fadhilah Rahmawati, M.Pd. selaku dosen pembimbing, Universitas Tidar, Bapak Achmad Asngari, dan SMA Negeri 2 Grabag. Atas segala bantuannya dalam penelitian ini sehingga penelitian ini dapat disusun berdasarkan faktafakta di lapangan yang nantinya diharapkan dapat dijadikan sebagai bahan masukan kepada sekolah dan penelitian lainnya.

\section{Daftar Pustaka}

[1] Hija, A., Nirawati, R., \& Prihatiningtyas, N. C., "Pengaruh Model Pembelajaran Group Investigation (GI) terhadap Kemampuan Pemecahan Masalah Matematis Siswa pada Materi Peluang Kelas X MIPA", Jurnal Pendidikan Matematika Indonesia, 1 (1), hlm 25-33, (2016).

[2] Zain, A. N., Supardi, L., \& Lanya, H., "Analisis Kesalahan Siswa dalam Menyelesaikan Materi Trigonometri", Sigma: E-Journal Unira, 3 (1), hlm 12-16, (2017).

[3] Tarida, L., "Studi Korelasi antara Nilai Ujian Nasional Matematika Tingkat SMA/SMK terhadap Nilai Matematika Terapan Taruna/i Akademi Maritim Nusantara (AMN) Cilacap", Jurnal Saintara, 2 (1), hlm 29-36, (2015).

[4] Renaissa, M. M., "Kesesuaian Soal Ujian Nasional Mata Pelajaran Matematika dengan Kisi-Kisi Ujian Nasional Berdasarkan Pemendiknas dan Indikator KTSP”, Universitas Sanata Dharma, (2011).

[5] Nurussafa'at, F. A., Sujadi, I., \& Riyadi, "Analisis Kesalahan Siswa dalam Menyelesaikan Soal Cerita pada Materi Volume Prisma dengan Fong's Shcematic Model for Error Analysis Ditinjau dari Gaya Kognitif Siswa (Studi Kasus Siswa Kelas VIII Semester II SMP IT Ibnu Abbas Klaten Tahun Ajaran 2013/2014", Jurnal Elektronik Pembelajaran Matematika, 4 (2), hlm 174-187, (2016).

[6] Jana, P., "Analisis Kesalahan Mahasiswa dalam Menyelesaikan Soal Matematika pada Pokok Bahasan Vektor", Jurnal Mercumatika: Jurnal Penelitian Matematika Dan Pendidikan Matematika, 2 (2), hlm 814, (2018).

[7] Mulyani, M., \& Muhtadi, D., "Analisis Kesalahan Siswa Dalam Menyelesaikan Soal Trigonometri Tipe Higher Order Thinking Skill Ditinjau Dari Gender", Jurnal Penelitian Dan Pembelajaran Matematika, 12 (1), hlm 1-16, https://doi.org/10.30870/jppm.v12i1.4851, (2019). 
[8] Arbain, J., Azizah, N., \& Sari, I. N., "Pemikiran Gender Menurut Para Ahli: Telaah atas Pemikiran Amina Wadud Muhsin, Asghar Ali Engineer, dan Mansour Fakih", Sawwa, 11, hlm 75-94, (2015).

[9] Yazidah, N. I., "Analisis Kesalahan Menyelesaikan Soal Pembuktian Geometri Euclid Ditinjau dari Gender pada Mahasiswa IKIP Budi Utomo Malang", Jurnal Pendidikan Matematika Universitas Muhammadiyah Prof. Dr. Hamka, 2 (1), hlm 71-80, (2017).

[10] Murni, W., "Pemaparan Metode Penelitian Kualitatif', UIN Maulana Malik Ibrahim Malang, hlm 1-17, (2017).

[11] Oktaviana, D., "Analisis tipe kesalahan berdasarkan teori newman dalam menyelesaikan soal cerita pada mata kuliah matematika diskrit", Jurnal Pendidikan Sains \& Matematika, 5 (2), hlm 22-32, (2017).

[12] Fadillah, S., "Analisis Miskonsepsi Siswa SMP dalam Materi Perbandingan dengan Menggunakan Certainty of Response Index (CRI)", Jurnal Pendidikan Informatika Dan Sains, 5 (2), hlm 247-259, (2016).

[13] Rahmawati, D., \& Permata, L. D., "Analisis Kesalahan Siswa dalam Menyelesaikan Soal Cerita Program Linear dengan Prosedur Newman" Jurnal Elektronik Pembelajaran Matematika, 5 (2), hlm 173185, (2018).

[14] Ariyunita, N., "Analisis Kesalahan Penyelesaian Soal Operasi Bilangan Pecahan", Universitas Muhammadiyah Surakarta, (2012).

[15] Nurjanah, S., \& Sunarto, "Analisis Kesulitan dalam Menyelesaikan Soal-Soal Fisika Materi Usaha dan Energi Siswa Kelas X SMK Taman Karya Jetis Yogyakarta", COMPTON: Jurnal Ilmiah Pendidikan Fisika, hlm 21-26, (2012).

[16] Meilanawati, P., \& Pujiastuti, H., "Analisis Kesalahan Mahasiswa Mengerjakan Soal Teori Bilangan Menurut Tahap Kastolan Ditinjau dari Gender", Jurnal Pendidikan Matematika STKIP Bina Bangsa Meulaboh, 7 (2), hlm 182-190, (2020).

[17] Rahmawati, F., "Pembelajaran Matematika pada Siswa Remaja dengan Kebutuhan Khusus di Sekolah Inklusi”, Indonesian Journal of Mathematics Education, 1 (1), hlm 53-58, (2018).

[18] Apriliawan, A., Gembong, S., \& Sanusi, "Analisis Kesalahan Penyelesaian Soal
Uraian Matematika Siswa MTS pada Pokok Bahasan Unsur-Unsur Lingkaran”, EJournal Universitas PGRI Madiun, (2013).

[19] Suciati, I., \& Wahyuni, D. S., "Analisis kesalahan siswa dalam menyelesaikan soal matematika pada operasi hitung pecahan pada siswa kelas v sdn pengawu", Jurnal Penelitian Dan Pembelajaran Matematika, 11 (2), hlm 129-144, (2018).

[20] Mulyadi, S., "Analisis Kesalahan Siswa Kelas dalam Menyelesaikan Soal Cerita Ditinjau dari Perbedaan Gender", APOTEMA: Jurnal Program Studi Pendidikan Matematika, 4 (1), hlm 80-86, (2018). 